\title{
Pathological Findings of Tenacibaculum maritimus Infection in Black Damselfish, Neoglyphieodon melas and Picasso Triggerfish, Rhinecanthus assasi in Red Sea, Egypt
}

\author{
Mohie Haridy ${ }^{1,4 *}$, Mahmoud Hasheim² ${ }^{2}$ Mohamed Abd El-Galil ${ }^{3}$, Hiroki Sakai ${ }^{4}$ and Tokuma Yanai ${ }^{4}$ \\ ${ }^{1}$ Department of Pathology and Clinical Pathology, Faculty of Veterinary Medicine, South Valley University, Qena 83523, Egypt \\ ${ }^{2}$ Department of Fish Diseases and Management, Faculty of Veterinary Medicine, New Valley Branck, Assuit University, El-Kharja, Egypt \\ ${ }^{3}$ Department of Fish Diseases and Management, Faculty of Veterinary Medicine, Sohag University, Sohag 82524, Egypt \\ ${ }^{4}$ Department of Veterinary Pathogenetic Science, United Graduated School of Veterinary Science, Gifu University, 1-1 Yanagido, Gifu 501-1193, Japan
}

\begin{abstract}
An outbreak of a disease with external body lesions in Picasso triggerfish (Rhinecanthus assasi) and black damselfish (Neoglyphieodon melas) has been observed in the indoor aquarium of NIOF, Hurghada, Egypt. Thirty Picasso triggerfish and thirty-five black damselfish were clinically affected with gross skin lesions. The affected fishes were euthanized for gross, histological and bacteriological examinations. The disease onset started after exposing the fish to catching and indoor rearing stress. Anorexia, erratic swimming and hemorrhagic skin and mouth ulcers and fin rot were the main symptoms and lesions among Picasso triggerfish and black damselfish. Single species of bacteria was isolated from skin ulcer, liver and spleen and was diagnosed as Tenacibaculum maritimus. The gross lesions were irregular shallow erosions and deep ulcers on the dorsal and lateral skin, sometimes on the head, mouth and fins, and occasionally, on the cornea. Histological findings, the hepatic tissue revealed fatty degeneration and focal liquefactive necrosis. Congestion, hemorrhage, hemosidrosis and lymphoid depletion was observed in spleen. The deep skin ulcers characterized by epidermal and muscular necrosis. Picasso triggerfish and black damselfish had lesions similar to those of natural infection and mortality rates of 50 and $60 \%$, respectively in experimental reproduction of the disease. The natural T. maritimus infection in Picasso triggerfish and black damselfish in Red Sea is not only a superficial skin lesion but also a systemic infection.
\end{abstract}

Keywords: Tenacibaculum maritimus; Rhinecanthus assasi; Neoglyphieodon melas; Pathology; Skin ulcer; Hurghada; Red Sea

\section{Introduction}

Marine tenacibaculosis is a serious bacterial disease affecting a great variety of marine fish especially cultured species. Both adult and young are susceptible but the young fish are seriously affected [1]. The filamentous organism Tenacibaculum maritimum (formerly FLexibacter maritimus) is the causal agent of 'marine flexibacteriosis', an important infectious disease affecting cultured marine fish in Japan and Europe [2-4]. Since fish farming became a steadily growing industry, outbreaks of tenacibaculosis have occurred everywhere in the world. It had been recorded in Japanese flounder, Paralichthys olivaceous and yellowtail Seriola quinqueradiata and other fishes in Japan [4,5]. In Spain, disease problems attributable to this pathogen have increased considerably during the last few years, threatening the culture of turbot, Scophthalmus maximus (L.), Atlantic salmon, Salmo salar L., and Coho salmon, Oncorhynchus kisuteh (Walbaum) [6-8]. In Scotland, tenacibaculosis caused serious mortalities in Dover sole Solea solea [9]. In Australia, T. marinmus has been identified as a pathogen of sea-caged Atlantic salmon, Salmo salar L., and rainbow trout, Oncorhynchus mykiss (Walbaum), and recently captured striped trumpeter, Latris lineata, yellow-eye mullet, Aldrichetta forsteri (Valenciennes), and black bream, Acanthopagrus butcheri (Munro) [10,11]. A comprehensive and detailed description of the causative organism i.e. T. maritimum has been reported [3,12-15], but there is shortage in the studies concerning with the pathology of the disease. T. maritimus infection was described in two established aquaculture species, Atlantic salmon and rainbow trout, and two potential aquaculture species, striped trumpeter and greenback flounder, Rhombosolea tapirina (Gunther). The main lesions were dermal and gill erosions [10]. Moreover, a necrotizing branchitis in gills of salmonids has been recorded $[10,16]$. We previously reported the epidemiology and microbiological findings of the outbreak of $T$. maritmum in Picasso triggerfishes Rhinecanthus assasi and black damsel Neoglyphieodon melas [17,18]. The aim of the present study is to describe the pathological findings of the natural T. maritimum outbreak in Picasso triggerfishes and black damselfishes in indoor aquarium, NIOF, Hurghada, Red Sea.

\section{Materials and Methods}

\section{Natural infection}

Picasso triggerfish, Rhinecanthus assasi and black damselfish Neoglyphieodon melas were caught and reared in the indoor aquaria of the National Institute of Oceanography and Fisheries (NIOF), Hurghada, Egypt since 2 weeks before onset of outbreak. Thirty and thirty -five Picasso triggerfish and black damselfish were clinically affected with gross skin lesions. The affected fishes were euthanized for gross and bacteriological examinations.

*Corresponding author: Mohie Haridy, Department of Veterinary Pathogenetic science, United Graduated school of Veterinary science, Gifu University, 1-1 Yanagido, Gifu 501-1193, Japan, Tel/Fax: 02-096-521-1223; E-mail: mohieharidy@svu.edu.eg

Received November 12, 2014; Accepted January 28, 2015; Published January 30, 2015

Citation: Haridy M, Hasheim M, El-Galil MA, Sakai H, Yanai T (2015) Pathological Findings of Tenacibaculum maritimus Infection in Black Damselfish, Neoglyphieodon melas and Picasso Triggerfish, Rhinecanthus assasi in Red Sea, Egypt. J Veterinar Sci Technol 6: 214. doi:10.4172/2157-7579.1000214

Copyright: ( 2015 Haridy M, et al. This is an open-access article distributed under the terms of the Creative Commons Attribution License, which permits unrestricted use, distribution, and reproduction in any medium, provided the original author and source are credited. 
Citation: Haridy M, Hasheim M, El-Galil MA, Sakai H, Yanai T (2015) Pathological Findings of Tenacibaculum maritimus Infection in Black Damselfish, Neoglyphieodon melas and Picasso Triggerfish, Rhinecanthus assasi in Red Sea, Egypt. J Veterinar Sci Technol 6: 214. doi:10.4172/21577579.1000214

Page 2 of 5

\section{Bacteriological examination}

Tissue smears and bacteriological swabs were taken from the skin erosions and ulcers of the natural infection. The swabs were plated into Hsu-Shotts media prepared in sea water, then incubated for $48 \mathrm{~h}$ at $25^{\circ} \mathrm{C}$. Single pure colonies were characterized biochemically. The biochemical tests included catalase, oxidase, nitrate and Congo red reduction tests, growth on sea water and sucrose, production of $\mathrm{H} 2 \mathrm{~S}$.

\section{Histopathological examination}

Necropsy of the affected fishes was performed and gross lesions were reported. The samples including skin lesions, liver and spleen were fixed in $70 \%$ ethanol solution, embedded in paraffin wax and sectioned at 3-5 $\mu \mathrm{m}$. The sections were stained with haematoxylin and eosin (H and E), Giemsa and Gram stains [10].

\section{Pathogenicity assays}

The experimental infection study was carried out at the lab of Fish Microbiology, NIOF, Hurghada, Egypt. Four equal groups (40 fish each) of healthy Picasso triggerfish and black damselfish, weighting $100 \pm 10 \mathrm{gm}$ obtained from coral reef in the marine site of NIOF were used. The fish were accommodated for 15 days before inoculation in 4 glass aquaria $(110 \mathrm{~L})$. Continuous aeration and filtration were maintained in each aquarium using an air pump and filter. The first group of each fish species was challenged by bath immersion for $18 \mathrm{hrs}$

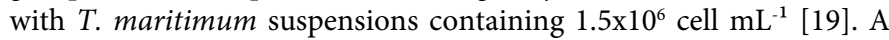
pure culture of T. maritimum isolate originally isolated from a case of natural infection in Picasso triggerfish and black damselfish was used for experimental induction of the disease. Another group of each fish species was used as control. The challenged and control groups were kept in $110 \mathrm{~L}$ glass aquarium with continuous flowing sea water at temperature $22 \pm 2{ }^{\circ} \mathrm{C}$. The clinical signs and mortalities were recorded daily for 14 successive days. Re-isolation of T. maritimum from skin lesions of the experimentally challenges fishes was performed.

\section{Results}

\section{Clinical history and gross lesions}

An outbreak of disease with external body lesions in Picasso triggerfish and black damselfishes has been observed in the indoor aquarium of National Institute of Oceanography and Fisheries (NIOF), Hurghada, Egypt. The disease onset started after exposing the fish to catching and indoor rearing stress. Anorexia, lethargy and hemorrhagic skin and mouth ulcers and fin rot were the main symptoms and lesions in affected fishes. The incidence of the infection depending on gross examination in randomly collected fishes was $25.0 \%$ and $29.2 \%$ in Picasso triggerfish and black damselfish, respectively.

The main clinical signs observed on the affected fishes were varied according to the fish species; Picasso triggerfish were anorexic, lethargic and had external body lesions. The affected Picasso tiger fish showed skin hemorrhagic ulcers (Figure 1A) and eroded and ulcerated mouth. Lesions were most typically seen as irregular shallow erosions on the dorsal and lateral skin, but were also seen on the head, mouth and fins, and occasionally, on the cornea. The most common lesion was erosion of the flank at the point of pectoral fin brushing. The main internal post mortem lesions were paleness and swelling of liver, spleen and stomach (Figure 1A and 1B). Moreover, ascetic fluid was observed around the intestine.

The gross lesions of affected black damselfish were mostly deep circular hemorrhagic ulcers surrounded by white zone of necrosis on the lateral skin and muscles (Figure 1C), fin rot and corneal opacity. The main post mortem lesions were congestion of liver and spleen. Enlarged, friable and yellowish liver with dark superficial spots (Figure 1D) and abundant serous fluid is seen in the abdominal cavity.

\section{Isolation and characterization of the bacterial strains}

Twenty three putative T. maritimum strains were isolated from ulcers on the tail and lateral sides of the body, liver and spleen of the affected fishes. The biochemical and physiological characteristics of all isolates were similar and allowed the presumed identification of the bacteria as T. maritimum (Table 1).

\section{Histopathology of natural infections}

The hepatic tissue in Picasso trigger and black damselfishes revealed fatty degeneration characterized by deposition of fatty globules intracytoplasmic in hepatocytes. The fatty change displaced and compressed the nuclei of hepaocytes to periphery changing them
$1 \mathrm{~A}$

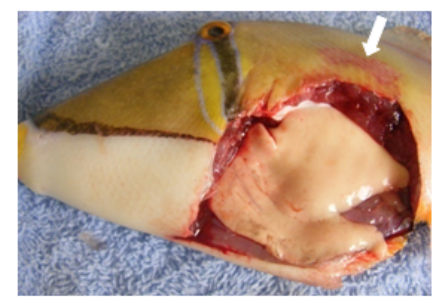

$1 \mathrm{C}$

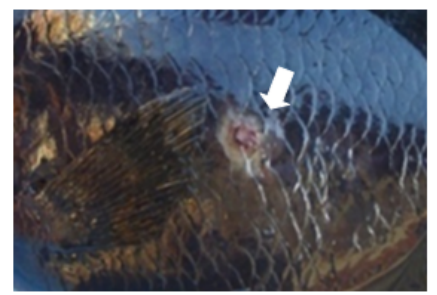

1B

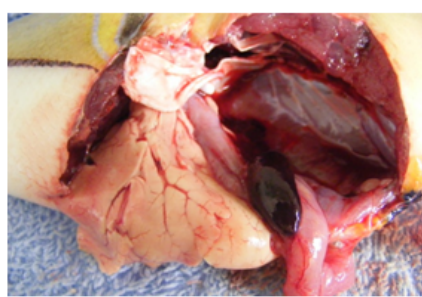

1D

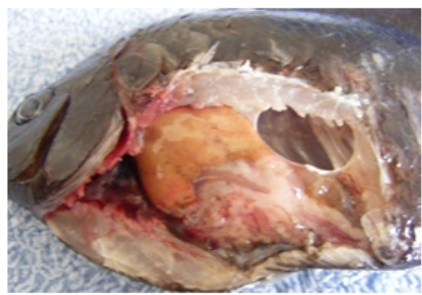

Figure 1: Gross lesions of Tenacibaculum maritimum infection in Picasso trigger fish were skin ulcer $(A)$, enlarged, friable and yellowish liver with rounded border $(A)$ and enlarged and congested spleen (B). Gross lesions of Tenacibaculum maritimum in Black Damsel fish were irregular deep skin ulcer (C), enlarged, friable and yellowish liver with dark superficial spots (D). Abundant serous fluid is seen in the abdominal cavity.

\begin{tabular}{|c|c|c|c|}
\hline & Tests & $\begin{array}{c}\text { Samples } \\
(\boldsymbol{T} \text {. } \text { maritimum })\end{array}$ & $\begin{array}{c}\text { Standard* } \\
\text { T. } \text { maritimum }\end{array}$ \\
\hline 1 & Colony shape & Uneven edge & Uneven edge \\
\hline 2 & Colony colour & Pale yellow & Pale yellow \\
\hline 3 & Gram stain & - ve rods & -ve rods \\
\hline 4 & Motility test & Motile & Motile \\
\hline 5 & Oxidase test & $+v e$ & $+v e$ \\
\hline 6 & Catalase test & $+v e$ & $+v e$ \\
\hline 7 & Nitrate reduction & $+v e$ & $+v e$ \\
\hline 8 & Congo red reduction & $+v e$ & $+v e$ \\
\hline 9 & Flexirubin-type pigments & $-v e$ & $-v e$ \\
\hline 10 & KOH & $-v e$ & $-v e$ \\
\hline 11 & Hydrolysis of Esculin & $-v e$ & $-v e$ \\
\hline
\end{tabular}

*According to Avendaño- Herrera et al. [16,19] and Mouriño et al. [27].

Table 1: The morphological and biochemical characteristics of isolated $T$. maritimum (samples) compared with standard isolate using conventional biochemical and API20E tests. 
Citation: Haridy M, Hasheim M, El-Galil MA, Sakai H, Yanai T (2015) Pathological Findings of Tenacibaculum maritimus Infection in Black Damselfish, Neoglyphieodon melas and Picasso Triggerfish, Rhinecanthus assasi in Red Sea, Egypt. J Veterinar Sci Technol 6: 214. doi:10.4172/21577579.1000214

to fat cells (Figure 2A and 2B). Focal areas of hepatic necrosis were observed characterized by severe destruction of hepatocytes leaving cellular debris and clumps of bacteria (Figure 2C and 2D). Necrosis of exocrine pancreatic part around the bile duct was observed (Figure 2E). Congestion, hemorrhage as well as hemosiderosis pigments of hepatic and splenic tissue were observed in black damselfish (Figure 2F). Spleen of Picasso triggerfish revealed lymphoid depletion with prominent sheathed arteries and macrophage cell infiltration (Figure $2 \mathrm{G}$ ) and focal heavy mononuclear cell infiltration (Figure $2 \mathrm{H}$ ).

Skin ulcers were superficial and deep in Picasso trigger and black damselfishes, respectively. Superficial ulcers were characterized by necrosis and loss of epidermis. Sub-epithelial inflammatory cell infiltration in skin was observed in Picasso trigger fishes (Figure 3A). Deep ulcers extended to include necrosis of the muscular tissue underlying the skin (Figure 3B and 3C). The muscular tissue revealed healing process composed of fibrosis with extensive mononuclear cell infiltration (Figure 3D). Gram negative rods were detected in Gram
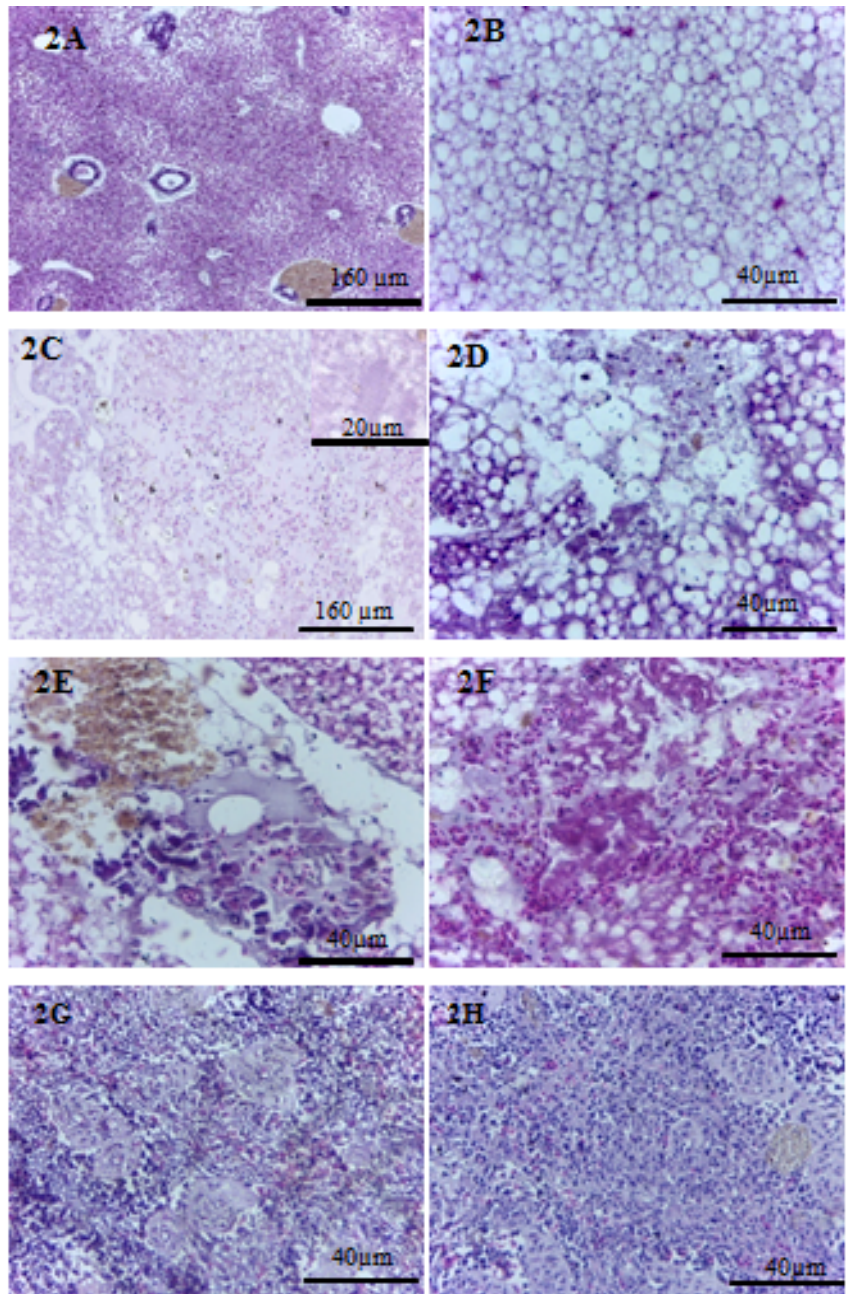

Figure 2: Histopathological lesions of Tenacibaculum maritimum infection in parenchymatous organs revealed hepatic fatty degeneration and hemosidrosis in black damsel fish (A), fatty change in liver of Picasso trigger fish (B), focal areas of necrosis in hepatic tissue of black damselfish $(\mathrm{C})$; note bacterial clumps in necrotic tissue (inset) and Necrosis of hepatic and exocrine part of pancreas in Picasso trigger fish ( $D$ and $E)$, hemorrhage in hepatic tissue of black damsel fish (F) and lymphoid depletion and inflammatory cell infiltration in spleen of Picasso trigger fish ( $\mathrm{G}$ and $\mathrm{H}), \mathrm{H}$ and $\mathrm{E}$.
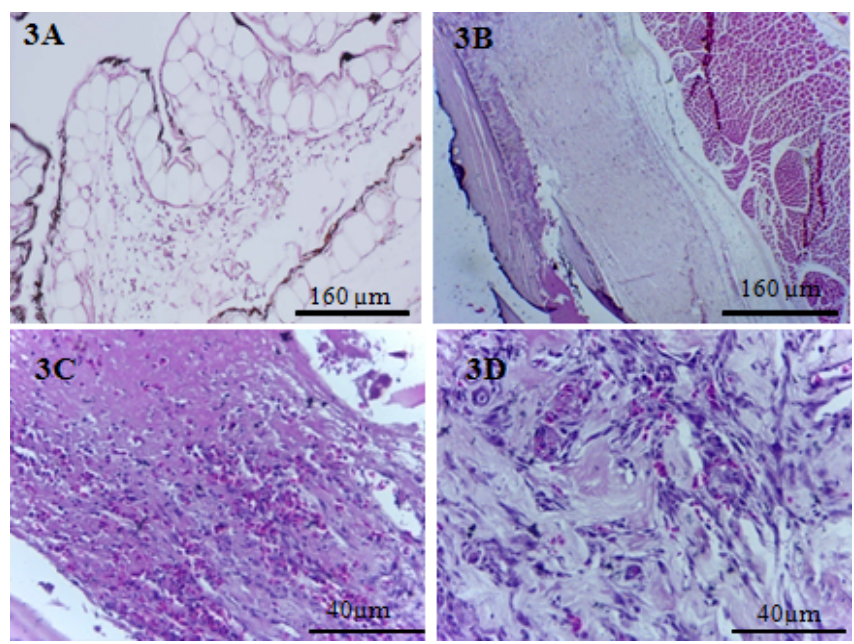

Figure 3: Histopathological lesions of Tenacibaculum maritimum infection in skin of Picasso trigger and black damsel fishes. Sub-epithelial leukocytic infiltration was seen in skin of Picasso trigger fish (A). Skin ulcer exhibited scale loss, epithelial necrosis and subcutaneous fibrosis and inflammatory cell infiltration (B). Higher magnification of "B" revealed extensive area of epithelial necrosis (C). Higher magnification of " $B$ " revealed focal area of fibrosis and inflammatory cell infiltration (D).

stained section from skin ulcer and liver smears of both Picasso trigger and black damselfishes.

\section{Pathogenicity assay}

The disease was re-produced experimentally in Picasso triggerfish and black damselfish using the T. maritimum isolate obtained from the natural infection. The lesions were skin hemorrhagic erosions and ulcers and focal erosions on mouth of the experimentally-challenged fishes. Three days after exposure, some fishes became anorexic with abnormal swimming behavior. Within 5 days post-exposure, hemorrhagic spots appeared on the lateral fins. By the end of the $1^{\text {st }}$ week post-exposure, mortalities commenced with lesions of skin erosions and ulcers on lateral sides, head, mouth and tail. By the end of the observation time (14 days) the mortalities increased to reach $50 \%$ and $60 \%$ in Picasso triggerfish and black damselfish, respectively. T. maritimum was reisolated in pure culture from the experimentally infected fish.

\section{Discussion}

Tenacibaculum maritimum is responsible for massive mortalities and severe economic losses in marine fish cultures worldwide including Japan, Scotland, Spain, France and North America [2,4,12,20,21]. T. maritimum has been isolated from Picasso triggerfish fishes and black damselfish in Red Sea for the first time [18]. The epidemiological and bacteriological findings have been published [17,18] and the pathological findings of this outbreak are described in this report. Several predisposing factors influencing the outbreaks and severity of lesions in tenacibaculosis were reported including high water temperature [10], recent transfer of fish from tanks to net-pens, absence of layer of sands in the tanks, existing gill pathology due to poor feeding management and water quality [10] and physical trauma due to net abrasion, cannibalism and skin parasites [22]. The onset of the present outbreak occurred just after exposing Picasso triggerfishes and black damselfishes to catching and indoor rearing stress.

In the present study, the naturally infected fishes showed the classical signs of tenacibaculosis such as anorexia, lethargy and external 
Citation: Haridy M, Hasheim M, El-Galil MA, Sakai H, Yanai T (2015) Pathological Findings of Tenacibaculum maritimus Infection in Black Damselfish, Neoglyphieodon melas and Picasso Triggerfish, Rhinecanthus assasi in Red Sea, Egypt. J Veterinar Sci Technol 6: 214. doi:10.4172/21577579.1000214

Page 4 of 5

body lesions including skin hemorrhagic ulcers (sometimes surrounded by white batch of necrotizing tissues), eroded and ulcerated mouth and fin and tail rot. These findings have been recorded for T. maritimum infections in Dover Sole Solea solea, Rock bream Oplegnathus fasciatus and wedge sole, Dicologoglos sacuneata (Moreau) [2-4,14].

The gross pathology of natural infections in Picasso triggerfish was irregular shallow erosions on the dorsal and lateral skin, but were also seen on the head, mouth and fins, and occasionally, on the cornea. On the other hand, black damselfish had deep circular hemorrhagic ulcers surrounded by white zone of necrosis on the lateral skin and muscles. Although the gross lesions in tenacibaculosis are similar in salmonid and non-salmonid species [10], some variations in the nature, sitting, and extend of lesions were found regard to the species [13] and age of fish [23]. The earliest lesions were superficial consistent fragmentation and degeneration of the epithelium, with infiltration of amorphous protein-like materials and occasionally intra-epithelial cellular inflammatory cells, plus congestion and hemorrhage of the superficial dermis. Variable scale loss, edema and a low level of inflammation in scale pockets, plus variable small adherent bacterial mats, are evident before full epithelial erosion [10]. Local scale loss results in hemorrhagic dermal erosion. The eroded zones subsequently evolved into deep skin ulcers might be due to adherence of overwhelming bacteria to eroded surfaces that spread throughout the necrotic tissue [10]. Deep ulcers in black damselfish might be a progression of erosions. The higher susceptibility of black damselfish might be a species difference or age-related $[10,14,20]$. Greenback flounder has been reported to be relatively resistant to marine tenacibaculosis, however striped trumpeter were easily to be infected [10]. Gill lesions in natural tenacibaculosis in salmonids are characterized by erosions of the free ends of one to several adjacent primary lamellae that variably present during outbreaks of skin disease and are often unassociated with skin lesions [10]. The gill lesions in the present study might not associate the skin lesions. Bernardet [22] reported that necrotic gill lesions in $T$. maritimum infection are not common and have been recorded in few species including Chinook salmon [13], Atlantic salmon and rainbow trout [10]. Neither gill lesions nor changes in the internal organs was observed in an outbreak of severe ulcerative lesions associated with $T$. maritimum in cultivated sole, Solea senegalensis (L) [24].

The histopathological changes in hepatic tissue in both Picasso trigger and black damselfishes were severe fatty changes and focal areas of hepatic necrosis. Necrosis of exocrine pancreatic part around the bile duct was also detected. The splenic tissue showed congestion, hemorrhage as well as hemosiderosis pigments in black damselfish and lymphoid depletion of Picasso triggerfish. The involvement of the internal organs in tenacibaculosis is suggested to be due to strong bacterial virulence and severe adverse condition [12,25]. Lack of an inflammatory cell infiltration in the histopathological lesions of the present study as well as degenerative changes in the parenchymatus organs might be due to the powerful exotoxin produced by $T$. maritimum which effectively prevents the host response $[10,23,26]$. Skin ulcers were superficial and deep in Picasso trigger and black damselfishes, respectively. Deep ulcers extended to include necrosis of the epidermis, dermis and the underlying muscular tissue. The muscular tissue revealed healing process composed of fibrosis with mononuclear cell infiltration. Complete loss of epidermis and dermis, as well as extensive necrosis of muscle layers, with mild-to-moderate inflammatory response with the presence of macrophages are main lesions in cultivated sole outbreak due to T. maritimum [24]. In the present study, although of minimal inflammatory cell infiltration in skin and hepatic lesions, mononuclear cell infiltration was observed in splenic and necrotized muscular tissue. The inflammatory cell response in tissues has discrepancy in literature. Mild- to moderate inflammatory response surrounding necrotized muscle fibers and severe ulcers was observed in cultivated sole outbreak [24]. In contrast, congestion and minimal inflammatory reaction was observed in muscles of salmonids naturally infected by T. maritimum. The discrepancies in these findings could be attributed to the differences in the immune response among fish species or to the stage of lesion development. Mononuclear cells in our study were associated with fibrosis of muscle fibers indicating some degree of healing process.

Finally, experimental re-production of the disease carried out according to Avendano- Herrera et al. [19], clearly demonstrated the pathogenic potential of the twenty three isolates. The symptoms and lesions observed in experimental infection were the same of the natural infection except for time progress. By the end of experiment, mortalities were $50 \%$ and $60 \%$ in Picasso triggerfish and black damselfish, respectively. T. maritimum was re-isolated in pure culture from the experimentally infected fish. A higher percentage of mortality (92.5\%) was observed in shrimp, Litopenaeus vannamei post-larvae after bath challenge with $1.2 \times 10^{8}$ colony forming unit $\mathrm{Ml}^{-1}$ [27]. However, mortalities were $80-100 \%$ and $20-40 \%$ in juvenile Japanese flounder Paralichthys olivaceus after a bath challenge with $10^{7.9}$ and $10^{6.9}$ colony forming unit $/ \mathrm{mL}$, respectively [28]. The morality rate is depending on fish species, method and dose of challenge and age fishes.

The lesions in parenchymatous organs including hepatic focal necrosis and fatty degeneration, pancreatic necrosis and lymphoid depletion has been observed in naturally infected Picasso triggerfishes and black damselfishes. The lesions is related directly to systemic infection of T. maritimum because it was the only isolated bacterium from deep skin ulcers and liver using different types of selective and non- selective media [18]. Recently, in intraperitoneal inoculation of T. maritimum in turbot, Psetta maxima L., multifocal necrotic areas in liver, kidney and pancreas were observed [29]. Immunoreactivity was distributed in macrophages around ellipsoidal blood vessels in spleen and renal interstitium in subcutaneous inoculation in addition to liver, gastrointestinal tract serosa, gills and heart in IP inoculation [29].

In conclusion, tenacibaculosis in Picasso triggerfishes and black damselfishes was caused by T. maritimum. Erosion and ulceration lesions of external surfaces were the most prominent clinical signs. Re-production of the disease experimentally and re-isolation of the organism from the skin lesions confirm Koch's postulates. The pathological findings of T. maritimum infection in Picasso triggerfishes and black damselfishes in Red Sea suggested a systemic infection.

\section{References}

1. Toranzo AE, Magarinos $B$, Romalde $J L$ (2005) A review of the main bacterial fish diseases in mariculture systems. J Aquaculture 246: 37-61.

2. Bernardet JF, Campbell AC, Buswell JA (1990) Flexibacter maritimus is the agent of 'Black patch necrosis' in Dove; sole in Scotland. Dis. Aquat. Org 8 : 233-237.

3. Campbell AC, Buswell JA (1982) An investigation into the bacterial aetiology of black patch necrosis' in Dover sole, Solea solea L. J. Fish Dis 5: 495-508.

4. Wakabayashi H, Hikida M, Masumura K (1986) Flexibacter maritimus sp. nov., a pathogen of marine fish. Int J Syst Bacteriol 36: 396-398.

5. Baxa DV, Kawai K, Kusuda R (1986) Characteristics of gliding bacteria isolated from diseases cultured flounder, Paralichthys olivaceous. Fish Pathol. 21: 251 285.

6. Devesa S, Barja JL, Toranzo AE (1989) Ulcerative skin and fin lesions in reared turbot, Scophthahnus maximus (L.). J Fish Dis 12: 323-333. 
Citation: Haridy M, Hasheim M, El-Galil MA, Sakai H, Yanai T (2015) Pathological Findings of Tenacibaculum maritimus Infection in Black Damselfish, Neoglyphieodon melas and Picasso Triggerfish, Rhinecanthus assasi in Red Sea, Egypt. J Veterinar Sci Technol 6: 214. doi:10.4172/21577579.1000214

7. Pazos F, Santos Y, Núñez S, Toranzo AE (1993) Increasing occurrence of Flexibacter maritimus in the marine aquaculture of Spain. FHS/AFS Newsletter 21: $1-2$.

8. Toranzo AE, Santos Y, Bandin I, Romalde JL, Ledo A, et al. (1990) Five years survey of bacterial fish infections in continental and marine aquaculture in Northwest of Spain. World Aquaculture 21: $91-94$

9. McVicar AH, White PG (1982) The prevention and cure of an infectious disease in cultivated juvenile Dover sole, Solea solea (L). Aquaculture 26: 213-222.

10. Handlinger J, Soltani M, Percival S (1997) The pathology of Flexibacter maritimus in aquaculture species in Tasmania, Australia. J. Fish Dis 20: 159168

11. Schmidtke L, Carson J, Howard T (1991) Marine Flexibacter infection in Atlantic salmon-characterization of the putative pathogen. In: Proceedings of the SALTAS Research Review. Seminar, (ed. by P. Valentine), pp. 25-39. SALTAS P/L, Hobart, Tasmania.

12. Alsina M, Blanch AR (1993) First isolation of Flexibacter maritimum from cultivated turbot (Scophthalmus maximus). Bull. Eur. Assoc. Fish Pathol 13: 157-160.

13. Chen MF, Henry-Ford D, Groff JM (1995) Isolation and characterization of Flexibacter maritimus from marine fishes of California. J Aquat Anim Health 7: 318-326.

14. López JR, Núńez S, Magariños B, Castro N, Navas Jl, et al. (2009) First isolation of Tenacibaculum maritimum from wedge sole, Dicologoglos sacuneata (Moreau). J Fish Dis 32: 603-610.

15. Wakabayashi H, Hikida M, Masumura K (1984) Flexibacter infection in cultured marine fish in Japan. Helgol Meeresunters 37: 587-593.

16. Avendaño-Herrera R, Magarinos B, Lo'pez-Romalde S, Romalde JL, Toranzo AE (2004) Phenotypic characterization and description of two major O-serotypes in Tenacibaculum maritimum strains isolated from marine fishes. Dis. Aquat. Org. 58: 1-8.

17. Abd El-Galil MA, Hashiem M (2011) Tenacibaculosis in Picasso tigger fish Rhinecanthus assasi and Black Damsel fish, Neoglyphieodon melas of Red Sea, Egypt. Life Sci J 8: 1166 -1171.

18. Abd El-Galil MA, Hashiem M (2012) Epidemiological and bacteriological studies on tenacibaculosis in some Red Sea fishes, Egypt. Internatl J Environ Sci Enginer 3: 25-32.
19. Avendano-Herrera $R$, Toranzo AE, Magarinos $B$ (2006) A challenge model for Tenacibaculum maritimum infection in turbot, Scophthalmus maximus (L.). $J$ Fish Dis 29: 371-374.

20. Bernardet JF, Kerouault B, Michel C (1994) Comparative study on Flexibacte maritimus strains isolated from farmed sea bass (Dicentrarchus labrax) in France. Fish Pathol 29: 105-111.

21. Ostland VE, La Trace C, Morrison D, Ferguson HW (1999) Flexibacter maritimus associated with a bacterial stomatitis in Atlantic salmon smolts reared in net-pens in British Columbia. J Aquat Anim Health 11: 35-44.

22. Bernardet JF (1998) Cytophaga, Flavobacterium, Flexibacter and Chryseobacterium infections in cultured marine fish. Fish Pathol 33: 229-238.

23. Baxa DV, Kawai K, Kusuda R (1988) In vitro and in vivo activities of Flexibacter maritimus toxins. Rep. Usa Mar Bio Inst Kochi Univ 10: 1-8.

24. Vilar P, Failde LD, Bermudez R, Vigaliano F, Riaza A, et al. (2012) Morphopathological features of a severe ulcerative disease outbreak associated with Tenacibaculum maritimum in cultivated sole, Solea senegalensis (L.). J Fish Dis 35: 437-445.

25. Cepeda C, Santos Y (2002) First isolation of Flexibacter maritimus from farmed Senegalese sole (Solea senegalensis, Kaub) in Spain. Eur. Assoc. Fish Patho 22: $388-329$.

26. van Gelderen R, Carson J, Nowak B (2011) Experimentally induced marine flexibacteriosis in Atlantic salmon smolts Salmo salar. II. Pathology. Dis Aquat Organ 95: 125-135.

27. Mouriño JL, Vinatea L, Buglione-Neto C, Ramirez CT, Vieira F, et al. (2008) Characterization and experimental infection of Flexibacter maritimus in hatcheries of post-larvae of Litopenaeus vannamei. Braz J Biol 68: 173-177.

28. Nishioka T, Watanabe K, Sano M (2009) A Bath Challenge Method with Tenacibaculum maritimum for Japanese Flounder Paralichthys olivaceus. Fish Pathol 44: 178-181.

29. Faidle LD, Losada AP, Bermudez R, Santos Y, Quiroga MI (2013) Tenacibaculum maritimum infection: Pathology and immunohistochemistry in experimental challenged turbot, Psetta maxima L. Microb Pathogenesis 65 $82-88$. 